\title{
Transplantation of storm-generated coral fragments to enhance Caribbean coral reefs: A successful method but not a solution
}

\author{
Virginia H. Garrison ${ }^{1}$ \& Greg Ward ${ }^{1,2}$ \\ 1. U.S. Geological Survey, 600 Fourth Street South, St. Petersburg, Florida 33701, U.S.A.; ginger_garrison@usgs.gov \\ 2. Florida Fish and Wildlife Conservation Commission, Fish and Wildlife Research Institute, South Florida Regional \\ Lab, 2796 Overseas Highway, 119, Marathon, Florida 33050; greg.ward@ MyFWC.com
}

Received 8-VII-2011. Corrected 16-XII-2011. Accepted 20-XII-2011.

\begin{abstract}
In response to dramatic losses of reef-building corals and ongoing lack of recovery, a small-scale coral transplant project was initiated in the Caribbean (U.S. Virgin Islands) in 1999 and was followed for 12 years. The primary objectives were to (1) identify a source of coral colonies for transplantation that would not result in damage to reefs, (2) test the feasibility of transplanting storm-generated coral fragments, and (3) develop a simple, inexpensive method for transplanting fragments that could be conducted by the local community. The ultimate goal was to enhance abundance of threatened reef-building species on local reefs. Storm-produced coral fragments of two threatened reef-building species [Acropora palmata and A. cervicornis (Acroporidae)] and another fast-growing species [Porites porites (Poritidae)] were collected from environments hostile to coral fragment survival and transplanted to degraded reefs. Inert nylon cable ties were used to attach transplanted coral fragments to dead coral substrate. Survival of 75 reference colonies and 60 transplants was assessed over 12 years. Only $9 \%$ of colonies were alive after 12 years: no A. cervicornis; $3 \%$ of A. palmata transplants and $18 \%$ of reference colonies; and $13 \%$ of $P$. porites transplants and $7 \%$ of reference colonies. Mortality rates for all species were high and were similar for transplant and reference colonies. Physical dislodgement resulted in the loss of $56 \%$ of colonies, whereas $35 \%$ died in place. Only A. palmata showed a difference between transplant and reference colony survival and that was in the first year only. Location was a factor in survival only for A. palmata reference colonies and after year 10. Even though the tested methods and concepts were proven effective in the field over the 12-year study, they do not present a solution. No coral conservation strategy will be effective until underlying intrinsic and/or extrinsic factors driving high mortality rates are understood and mitigated or eliminated. Rev. Biol. Trop. 60 (Suppl. 1): 59-70. Epub 2012 March 01.
\end{abstract}

Keywords: Acropora cervicornis, A. palmata, coral mortality, Porites porites, reef restoration, coral transplantation.

Continuing declines and the lack of recovery on coral reefs worldwide have sparked renewed calls for action by the scientific, conservation, and reef management communities (e.g., Bruno \& Selig 2007, Mumby \& Steneck 2008, Rinkevich 2008, Teplitski \& Ritchie 2009). Consensus exists around the need to maintain as much genetic diversity, structural and biological integrity, and ecological services as possible if reefs are to be sustainable over time (e.g., Roberts et al. 2006, Shearer et al. 2009). Less agreement surrounds how best to achieve those goals and how to proceed in response to declining abundance of corals and other reef organisms. In cases of acute physical damage to reefs, such as in ship groundings, sophisticated engineering methods have been developed to mitigate damage and to maximize recovery and are used in combination with substrate stabilization and colony transplantation (e.g., Jaap et al. 2006). But increasingly, loss of live coral has been related to disease and abnormally high water temperatures and not to direct impacts from human activities (e.g., Miller et al. 2009). As researchers work to deepen understanding of reef ecology, coral 
reproduction, disease processes, and predation and to identify environmental drivers and effects from a changing climate, what is the appropriate response to the continuing loss of coral? What response at the local level will most effectively reduce further losses, minimize species extinctions, guard against loss of reproductive capacity, and maintain reef services such that local reefs and the well-being of human communities are simultaneously maintained (Knowlton 2006)?

Recently, restoration strategies have focused on the broader conservation effort, emphasizing the need to combine local management actions, such as establishment of no-harvest marine reserves and effective management of the coastal zone (both terrestrial and marine), with direct actions, such as transplantation (Epstein et al. 2005, Edwards \& Gomez 2007, Mumby \& Steneck 2008, Young 2000). Transplantation of coral colonies or fragments, whether from aqua-, mariculture or harvesting from a healthy colony, has been the most frequently recommended action for increasing coral abundance on damaged or degraded reefs and for conserving listed or "at-risk" species (e.g., Epstein et al. 2005, Edwards \& Gomez 2007, Rinkevich 2008, Teplitski \& Ritchie 2009). Yet there is a deepening awareness that no habitat, once damaged or degraded, can be restored to its original condition (Young 2000) and that the basic factors causing declines must be addressed if restoration of reefs and conservation of threatened reef species are to succeed over time (Edwards \& Clark 1998, Birkeland 2004, Kaufman 2006, Bruno \& Selig 2007). It has been suggested that newly developed molecular tools be used to optimize selection of coral propagules for cultivation and transplantation, to deepen our understanding of transplant survival (Baums 2008, Vollmer \& Kline 2008), and to identify and maximize the genetic diversity of transplants (Shearer et al. 2009), which is considered essential. Debate continues over the effectiveness of transplantation in conserving threatened coral species, increasing coral abundance, and accelerating reef restoration or enhancement at ecologically relevant temporal and spatial scales. This controversy is due in part to the small scale of transplant studies compared to the scale of reef damage (e.g., Edwards \& Gomez 2007) and the relatively short duration of most studies. Published research documenting transplant survival for 5 years or more is rare in the scientific literature (Bruckner \& Bruckner 2006, Garrison \& Ward 2008, Bruckner et al. 2009), although reports from proprietary restorations (e.g., ship groundings) exist but are difficult to access. Recently, a few large-scale transplantation studies have been initiated (Normile 2009). Their findings after 5 years, 10 years and beyond will be of great interest.

In 1999, a small-scale coral fragment transplantation project was initiated in a Caribbean marine protected area (Virgin Islands National Park, U.S. Virgin Islands). The primary objectives were to (1) identify a source of coral colonies for transplantation that would not result in damage to reefs, (2) test the feasibility of collecting and transplanting stormgenerated coral fragments, and (3) develop a simple, inexpensive method for transplanting fragments that could be conducted by the local community. The ultimate goal was to enhance abundance of threatened reef-building species on local reefs. Although small in scope, this is one of only two long-term studies of coral transplants. The survival and growth of transplant and reference colonies over 12 years are presented, as are lessons learned.

\section{MATERIALS AND METHODS}

Study: This study was conducted from May 1999 to April 2011 on four reefs within Virgin Islands National Park (VINP, St. John, U.S. Virgin Islands; Fig. 1). The study sites, experimental design, field methods (coral fragment collection, handling, transport, placement and orientation), criteria for attachment-substrate, data collection and analysis, and statistical models are detailed in Garrison \& Ward (2008), as are analysis and interpretation of the first 5 years (1999-2004) of data. Briefly, unattached storm-produced fragments of three 


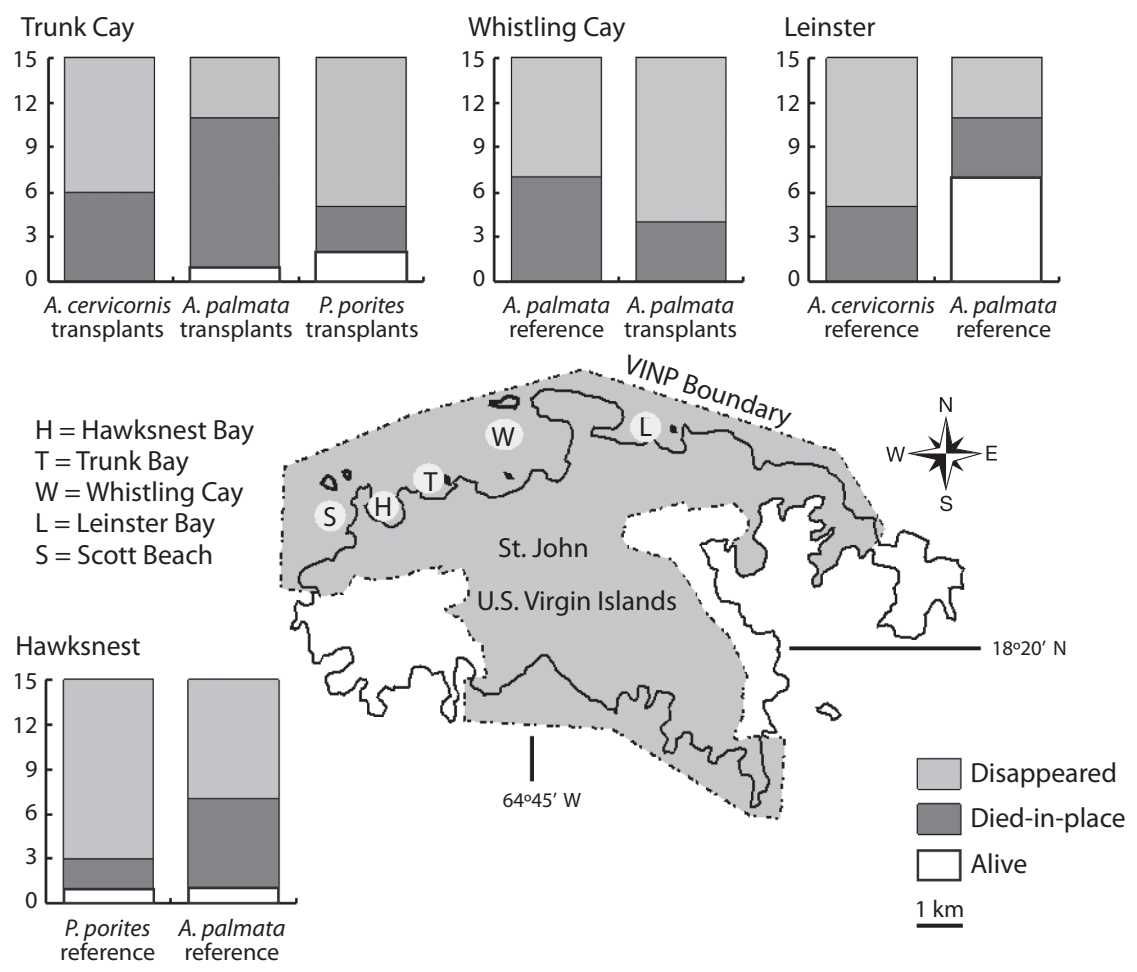

Fig. 1. Map of transplant and donor reefs in Virgin Islands National Park (VINP), St. John, U.S. Virgin Islands. Bar graphs represent the proportion of transplants and reference colonies that survived (white), died in place (dark gray), or were lost to displacement (disappeared; light gray) for each species at each site at 12 years (2011).

fast-growing Caribbean species [Acropora palmata (Lamarck, 1816) (elkhorn coral), A. cervicornis (Lamarck, 1816)(staghorn coral), and Porites porites (Pallas, 1766)(finger coral)] were collected from shallow (1-3m) sandy or bare substrate unfavorable for survival due to abrasion and tumbling (e.g., Bowden-Kerby 2001) and were transplanted to degraded reefs. These three species were chosen based on their life histories and reproductive strategies: all are fast growing; all colonize primarily via fragmentation; and healthy-appearing fragments of all three species were available in sufficient numbers for transplantation. Transplant reefs were selected based on similarity to fragment donor reefs in regard to depth, substrate type, water quality, water-mass turnover, and the presence of dead, intact A. palmata skeletons for attachment of transplants. Inert nylon cable ties were selected over uncoated wire, monofilament line, and underwater epoxy to secure the fragments to dead, standing A. palmata skeletons or other reef framework (see Garrison \& Ward 2008).

To follow the natural mortality rates of each of the three species over the timespan of the experiment and to control for environmental/site effects, reference colonies on donor and transplant reefs were selected to be as similar to transplanted fragments as possible, based on size, depth, and exposure to ocean swells (Table 1). There was no reference colony monitoring at Scott Beach due to hazardous boat traffic, and coral abundance was too low at Trunk Cay and Scott Beach for monitoring. One hundred thirty-five corals (60 transplanted fragments and 75 reference colonies) were tagged, photographed, measured, and qualitatively assessed 
TABLE 1

The numbers of monitored reference colonies and transplanted fragments are shown for each species (Acropora cervicornis, A. palmata, and Porites porites) by site. Source reefs of transplanted fragments are indicated (adapted from Garrison \& Ward 2008)

\begin{tabular}{|c|c|c|c|c|c|}
\hline $\begin{array}{l}\text { St. John, U.S. } \\
\text { Virgin Islands }\end{array}$ & $\begin{array}{l}\text { Latitude } \\
\text { Longitude }\end{array}$ & Coral species & $\begin{array}{l}\text { Number of } \\
\text { reference } \\
\text { colonies }\end{array}$ & $\begin{array}{l}\text { Number of } \\
\text { fragments } \\
\text { transplanted }\end{array}$ & $\begin{array}{c}\text { Source of } \\
\text { transplanted } \\
\text { fragments }\end{array}$ \\
\hline Trunk Cay & $\begin{array}{l}18.353 \mathrm{~N} \\
64.763 \mathrm{~W}\end{array}$ & $\begin{array}{l}\text { A. cervicornis } \\
\text { A. palmata } \\
\text { P. porites }\end{array}$ & & $\begin{array}{l}15 \\
15 \\
15\end{array}$ & $\begin{array}{c}\text { Scott Bay } \\
\text { Leinster Bay } \\
\text { Scott Bay }\end{array}$ \\
\hline Hawksnest Bay & $\begin{array}{l}18.347 \mathrm{~N} \\
64.780 \mathrm{~W}\end{array}$ & $\begin{array}{l}\text { A. palmata } \\
\text { P. porites }\end{array}$ & $\begin{array}{l}15 \\
15\end{array}$ & & \\
\hline Whistling Cay & $\begin{array}{l}18.372 \mathrm{~N} \\
64.747 \mathrm{~W}\end{array}$ & A. palmata & 15 & 15 & Leinster Bay \\
\hline Leinster Bay & $\begin{array}{l}18.363 \mathrm{~N} \\
64.750 \mathrm{~W}\end{array}$ & $\begin{array}{l}\text { A. cervicornis } \\
\text { A. palmata }\end{array}$ & $\begin{array}{l}15 \\
15\end{array}$ & & \\
\hline Total colonies & & $\begin{array}{l}\text { A. cervicornis } \\
\text { A. palmata } \\
\text { P. porites } \\
\text { All species }\end{array}$ & $\begin{array}{l}15 \\
45 \\
15 \\
75\end{array}$ & $\begin{array}{l}15 \\
30 \\
15 \\
60\end{array}$ & \\
\hline
\end{tabular}

at 6-month intervals from May 1999 to July 2001, annually from 2001 to 2004, 2009, and 2011. For the year-12 assessment in 2011, all transplanted fragments that were in place on the reef and reference colonies, alive or dead, were photographed, live tissue was measured, and the presence of lesions, disease signs, paling, and predators was recorded.

Data analysis: In survivorship analyses, coral colonies were considered dead and were removed from further inclusion in the dataset if: (1) the entire colony or fragment had disappeared and could not be relocated (physical dislodgement), or (2) live tissue was not observed (100\% tissue loss). Differences in survival probability were assessed using the generalized linear model module of Statistica 6.0 with a specified binomial distribution and complimentary log-log (clog-log) link. The clog-log link function is recommended when data are "interval censored" (i.e., mortality occurs in continuous time, but is observed at discrete intervals; Singer \& Willett 2003). Logistic regression procedures offer an alternative to ordinary least-squares regression, since bivariate outcomes (e.g., survival or death) seldom meet statistical assumptions required for ordinary regression (Peng et al. 2002).

After 12 years, the complexity of the experimental design and size of the data set resulted in categorical independent variables that were often defined by low sample sizes and/or risk sets. In conjunction with coarsening of sampling periods over a relatively long-duration study, a more parsimonious linear time effects model was chosen to avoid problems in model fitting associated with maximum-likelihood algorithms (e.g., model convergence, coefficient stability). Based on previous analyses of the 1999-2004 data set (Garrison \& Ward 2008), a linear regression model was chosen to describe risk sets over time and was allowed to interact non-proportionally with time. Parameter effects were included based on significant improvements $(\alpha=0.05)$ in the log-likelihood ratio, against the $\chi^{2}$-distribution, relative to a constant time-effects model (i.e., intercept only, hazard is constant through time).

\section{RESULTS}

Coral survival: After 12 years, only $9 \%$ (12) of the initial 135 colonies were alive: $3 \%$ 
of A. palmata transplants ( 1 of 30 ) and 18\% (8 of 45) of reference colonies; no A. cervicornis colonies; and $13 \%$ ( 2 of 15 ) of P. porites transplants and one reference colony (7\%; Fig. 2). The mean mortality rates of $A$. palmata and $P$. porites colonies remained constant over the study (31 and 33\% $\mathrm{yr}^{-1}$ likelihood of colony loss, respectively), whereas for A. cervicornis the mortality rate increased on average by a factor of 1.5 annually (Fig. 2; Garrison \& Ward 2008). Acropora palmata transplants were 2.3 times more likely to die in the first year than reference colonies, but not thereafter (Fig. 2). There was no significant difference between transplant and reference colony survival for A. cervicornis $\left(\chi_{(0.05,2}^{2}=0.359\right.$, $\mathrm{p}=0.836), P$. porites $\left(\chi_{(0.05,3)}^{2}=1.848, \mathrm{p}=0.605\right)$, or between A. palmata colonies transplanted from Hawksnest Bay to Trunk Cay and reference colonies in Hawksnest Bay $\left(\chi_{(0.05,2)}^{2}\right.$ $=2.51, \mathrm{p}=0.285$; Fig. 1). However, the mean probability of $A$. palmata transplant mortality in Whistling Cay was 4.8 times greater than the Leinster Bay reference colonies in the first year of the study $\left(\chi_{(0.05,1)}^{2}=11.74, \mathrm{p}<0.001\right)$ but did not significantly differ in the year-to-year rate of decline thereafter.

Over the 12 -year study, $56 \%$ of the initial 135 corals were lost due to physical dislodgement and $35 \%$ died in place. The relative roles of physical dislodgement and mortality in place varied among years (Fig. 2). Physical dislodgement was the major cause of mortality of transplants and reference colonies in the first year $(67 \%$ and $75 \%$, respectively). Mortality in place played a greater role in A. palmata $(56 \%)$ than in A. cervicornis (47\%) or P. porites losses (27\%; Fig. 2) and was most likely the result of disease, predation, high-temperature stress, or some combination. Physical damage was observed on most colonies at all sites and at most assessments, yet damage to colonies did not predict future survival/morality. Many colonies sustained serial damage only to survive and grow while others died despite no visible physical damage.

Survival of $A$. palmata transplants $\left(\chi_{(0.05,3)}^{2}=2.804, \mathrm{p}=0.246\right)$ and A. cervicornis and $P$. porites transplants and reference colonies did not show a site effect, whereas survival of A. palmata reference colonies differed significantly among sites (Table 2 and Fig. 1; Leinster 47\%, Hawksnest 7\%, and Whistling Cay $0 \%$ ). In the first year, A. palmata reference colonies exhibited a $12 \% \mathrm{yr}^{-1}$ mean probability of mortality at all sites. Reference colonies in Leinster Bay continued on this trajectory for 12 years, whereas the mean mortality rate at Whistling Cay and Hawksnest Bay increased annually by 1.25 - and 1.32 -fold, respectively $\left(\chi_{(0.05,2)}^{2}=8.688, \mathrm{p}<0.013\right)$.

The initial log-mean live-tissue size of transplanted coral fragments differed from reference colonies across all species, with

TABLE 2

Reduced linear model, logistic regression results of the survival of 45 Acropora palmata reference colonies: 15 colonies each on Leinster Bay, Hawksnest Bay, and Whistling Cay reefs. Survivorship was monitored for 12 years. Probability of mortality of reference colonies at Leinster Bay did not change over time, whereas probability of A. palmata reference colony mortality increased annually by a factor of 1.25 on Hawksnest and 1.32 on Whistling Cay reefs

\begin{tabular}{lcccccc}
\multicolumn{1}{c}{ Reduced linear model } & $\beta$ & SE $\beta$ & Wald's $\chi^{2}$ & d.f. & p & \multicolumn{2}{c}{ Hazard ratio $\left(e^{\beta}\right)$} \\
Intercept & -2.01 & 0.23 & 80.53 & 1 & $<0.001$ & NA \\
$\begin{array}{l}\text { Hawksnest Bay colony survival } x \\
\text { time interaction }\end{array}$ & 0.22 & 0.06 & 12.79 & 1 & $<0.001$ & 1.25 \\
$\begin{array}{l}\text { Whistling Cay colony survival x } \\
\text { time interaction }\end{array}$ & 0.28 & 0.07 & 17.37 & 1 & $<0.001$ & 1.32 \\
\hline
\end{tabular}

Logit parameter estimates (ß) and standard errors, Wald's chi-square statistics (Wald $\chi^{2}$ ), degrees of freedom (d.f.), significance test results (p), and Hazard ratio [( $e^{\beta}$; an estimate of the size of effect of time on the base hazard (in this case, the intercept estimate)]. 

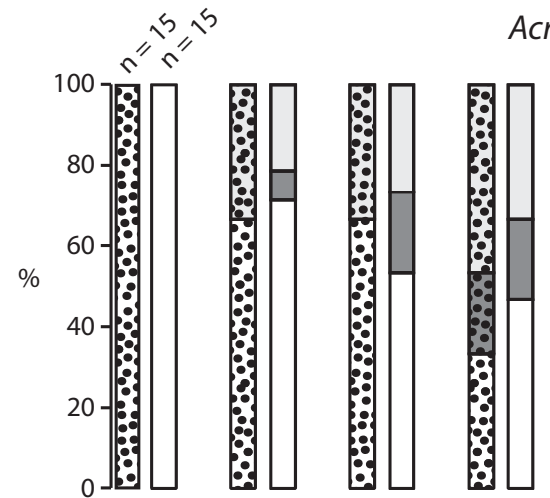

Acropora cervicornis
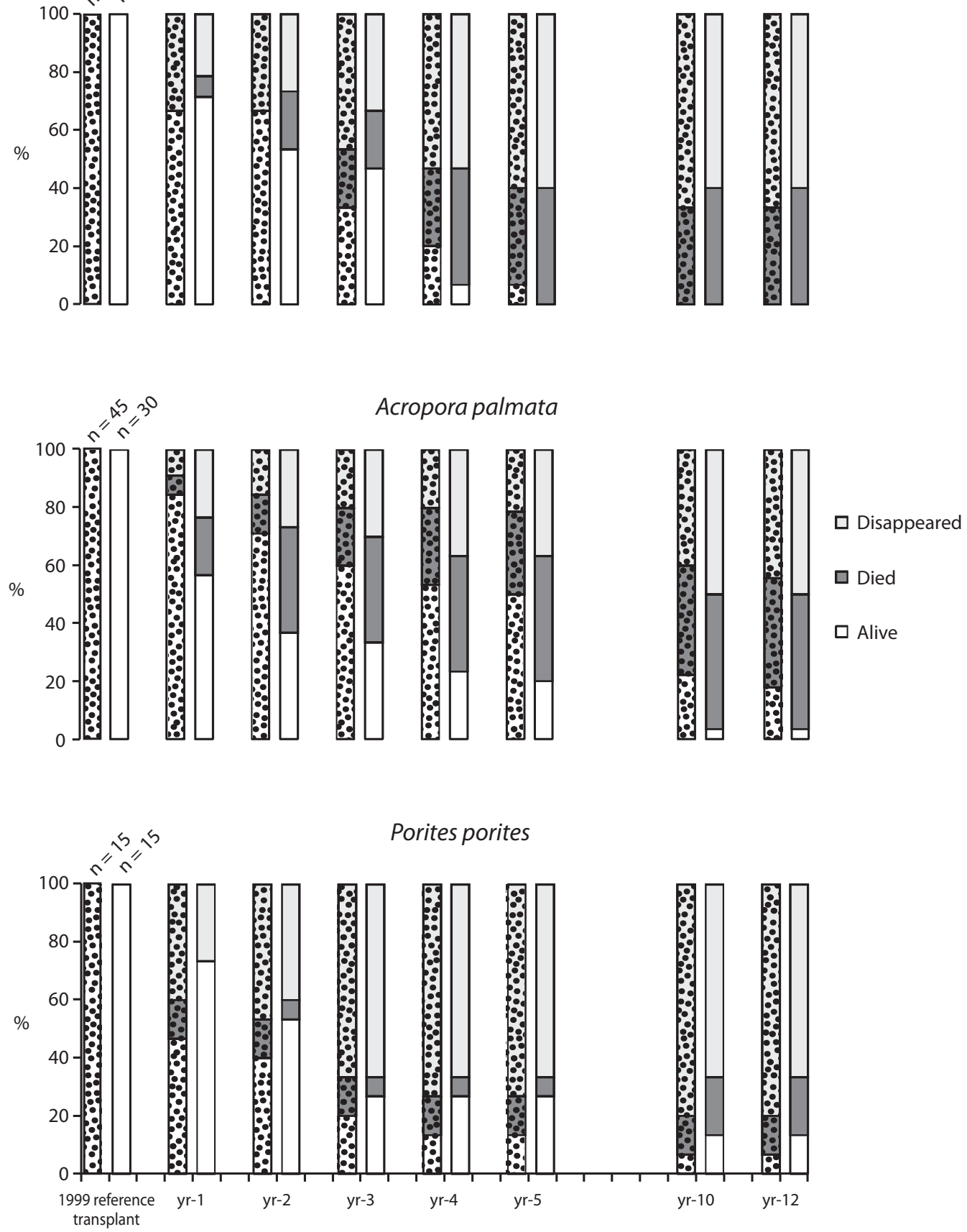

Fig. 2. The percentage of transplants (solid color bars) and reference colonies (pebble-texture bars) that survived (white), died in place (dark gray), or were lost to displacement (light gray) for each species over 12 years. 
reference colonies generally larger than transplants (see Table 2, Garrison \& Ward 2008). Size was a factor in survival only for A. palmata colonies in the first 5 years; the probability of mortality or dislocation of an $A$. palmata colony or transplant in the following year decreased by $15 \%$ per year with every 0.1 unit increase in log-maximum colony length over the first 5 years $(\beta=-1.60,95 \%$ C.I. $=-2.59$, -0.61; Garrison \& Ward 2008).

Colony growth: Two of the three transplants and 67\% (6/9) of the reference colonies alive at 12 years had increased in size. Maximum diameter of the single surviving $A$. palmata transplant increased more than 6-fold over the 12-year study [from $20 \mathrm{~cm}$ in 1999 to $130 \mathrm{~cm}$ prior to being physically dislodged in spring 2011 (Fig. 3)].
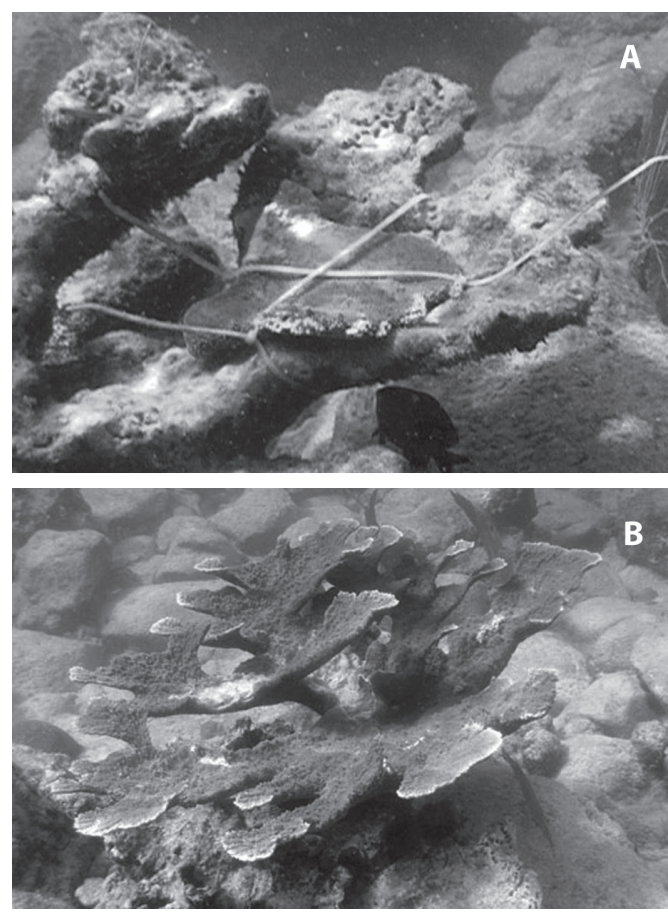

Fig. 3. Images of transplanted Acropora palmata fragment that survived 12 years. Top image: fragment when it was transplanted in 1999 (20 cm maximum dimension); bottom image: same transplanted fragment had grown to $130 \mathrm{~cm}$ maximum dimension in 2009.
Cost: Transplantation costs were low despite the small scale of the project and use of boats and scuba, all of which would be expected to increase the cost per transplant (Garrison \& Ward 2008). Cost of all materials, use of a boat and scuba, and scientist salary totaled US\$21 per transplant (Garrison \& Ward 2008). Cost would decrease further to a fraction of US\$1 per transplant for nylon cable ties if all work was conducted by volunteers on snorkel (Garrison \& Ward 2008). Collection, transportation, and attachment of each fragment to a reef 1 - $5 \mathrm{~km}$ distant required $0.6 \mathrm{hr}$ per fragment (Garrison \& Ward 2008).

\section{DISCUSSION}

The transplantation methods and concepts tested in the field over the 12-year study were shown to work. (1) Storm-produced coral fragments of A. palmata, A. cervicornis, and $P$. porites that were collected, transplanted, and attached to the reef using nylon cable ties had survival rates similar to reference colonies over 12 years. (2) No damage was inflicted on reefs or coral colonies in obtaining coral transplants. (3) Although physical displacement was the primary cause of mortality overall, the loss of a greater proportion of reference colonies than transplants to physical displacement supports the effectiveness of inexpensive and easyto-use cable ties for transplant attachment and confirms conclusions reached by others (Bruckner \& Bruckner 2001, Williams \& Miller 2010, Forrester et al. 2011). However, concepts and processes shown to work in the field do not necessarily translate into viable solutions for coral reef rehabilitation.

Coral mortality was striking with loss of all A. cervicornis by year-5 and most A. palmata and $P$. porites transplant and reference colonies by year-12 (Fig. 2). Although the high rates of mortality observed could be an artifact of small sample size and the dramatic diminishing of sample size through time, the findings are consistent with most Caribbean region research (e.g., Hughes 1994, Aronson \& Precht, 1997, 2001, Rogers 1999, Bruckner et 
al. 2009). Patches of healthy A. palmata and A. cervicornis exist (e.g., Vargas-Ángel \& Thomas 2002, Vargas-Ángel et al., 2003) but the regional picture is one of decline (e.g., Gardner et al. 2003, Rogers et al. 2009, and references therein). These findings paint an unambiguous picture of dynamic turnover of individual coral colonies on shallow-water Caribbean reefs and present a bleak outlook for the (1) long-term survival of transplants of these species and (2) the viability of two of the study species $-A$. cervicornis and $P$. porites. Both A. palmata and $A$. cervicornis have been key reef-building species in the Caribbean for thousands of years (e.g., Aronson \& Precht 1997, Pandolfi et al. 2005) and even though the life spans of individual colonies may be relatively short, populations may persist over time (Jaap et al. 2006). Nonetheless, the accelerating decline of $A$. cervicornis documented in the first 5 years and the high mortality rates of transplants and reference colonies of all three species documented here invoke concern.

Most coral transplantation research spans months, with few studies continuing for more than 2 years. Acropora palmata transplant survival documented in this study was similar to but lower than that reported in the only other long-term study of reattached A. palmata fragments (Bruckner et al. 2009), despite the considerable difference in scale of the studies [n=30 this study (VI); $\mathrm{n}=1857$, Mona Island, Puerto Rico (PR)]. The difference in fragment survival between the two studies narrowed from year-2 (43\% VI; 57\% PR, Bruckner \& Bruckner 2001] to year-10 (3\% VI; 6\% PR, Bruckner et al. 2009), indicating a realistic range of A. palmata fragment survival over time that could be expected in restoration efforts in the NE Caribbean. Storm-generated coral fragments were selected as the source of corals to transplant in this study because (1) intact corals were not damaged to create transplants, (2) fragment survival was maximized by attachment to the substrate (Williams \& Miller 2010, Forrester et al. 2011), and (3) damage to intact colonies from unattached fragment projectiles was reduced. A valid concern is that storm-generated fragments may have lower survival rates as a result of damage sustained during the fragmentation process itself and from subsequent abrasion. However, similar survival rates for transplants and reference colonies were documented for three of the four sets of transplants (A. cervicornis, P. porites, and A. palmata Trunk transplants/Hawksnest reference colonies), indicating that damage to transplants from the natural fragmentation process, or from collection and transplantation was not a factor in survival.

The high mortality of transplants and reference colonies overall indicates that environmental (extrinsic) and/or organismal (intrinsic genotypic or molecular-level function) factors and not transplant/reference status or experimental methodology were driving mortality. An extrinsic factor, storm-generated swells, appeared to play a key role. Physical dislodgement caused more than one-half of $A$. cervicor$n i s$ and $P$. porites colony mortality and nearly one-half of $A$. palmata transplant and reference colony mortality (Fig. 2). Surprisingly, the effect of location on survival of A. palmata colonies was not related to degree of direct exposure to ocean swells or distance from human activities. The site with highest $A$. palmata transplant and reference colony mortality (Whistling Cay) was the most protected from ocean swells, farthest from the island of St. John and associated pollution, and subjected to the least human activity (Fig. 1). The sites with lowest mortality (Leinster and Hawksnest) were directly exposed to storm swells and human activities (boats and snorkeling) and directly adjacent to the island and a road (Fig. 1). Reef architecture or bathymetric configuration at each site may have differentially enhanced or impeded water movement and have been a factor driving differences in mortality observed among sites. Intrinsic factors such as genotypes that produce faster growth or stronger and less brittle skeletons could account for the apparent robustness of colonies that survived strong storm swells at the lowermortality sites (Bowden-Kerby 2009). Similarly, although disease-like lesions were observed 
at all sites, colonies with disease-resistant genotypes or more robust immune function would be more likely to resist and survive infection (e.g., Ritchie 2006, Rosenberg et al. 2007, Vollmer \& Kline 2008, Teplitski \& Ritchie 2009). Multiple environmental factors that may have adversely impacted corals during the study period include elevated water temperatures, disease, chemical pollutant or nutrient influx, changes in salinity, acidification, sedimentation, predation, and the more subtle effects from loss of top predators or herbivores on reefs. Possible intrinsic factors include impaired immune function due to genotype (disease resistance; Vollmer \& Kline 2008); immunosuppressors in the environment; changes in the microbial community of the coral holobiont (Ritchie 2006, Rosenberg et al. 2007, Teplitski \& Ritchie 2009); impaired calcification; and/or genetic sensitivity to environmental stressors. The factors driving differences in survival among sites remain unknown but multiple factors are likely (e.g., Birkeland 2004, Bruno et al. 2007, Muller et al. 2008, Nyström et al. 2008).

Many restoration scientists have stressed the need for coral transplantation to be sustained over time and at an appropriate scale if it is to be effective (e.g., Rinkevich 1995, 2008, Epstein et al. 2005, Edwards \& Gomez 2007). Results from this small-scale study bring into question whether such a major effort could be successful if underlying factors driving declines are not also addressed. In cases where coral mortality and reef degradation are primarily due to acute damage from humans, transplantation of coral colonies might help to conserve coral species and help accelerate reef recovery, but only if undertaken in conjunction with other actions such as management of human activities through use of marine protected areas, enforcement of marine and terrestrial regulations, and education (e.g., Epstein et al. 2005, Rinkevich 2005, 2008). If chronic global or regional stressors such as abnormal water temperatures, contaminants, or disease are the primary drivers of declines on coral reefs, it is difficult to understand how transplantation, even on the scale of tens of thousands of transplants across tens of hectares, could succeed in conserving species or restoring reefs over time if the drivers of mortality and degradation are not addressed (Birkeland 2004, Kaufman 2006). Is $3 \%$ survival of transplants at 12 years an acceptable outcome? Will 3\% transplant survival at 12 years be effective in halting declines of threatened coral species, maintaining genetic diversity and ecosystem services and functions, or staving off species extinction if corals on the surrounding reefs are dying at a similar rate?

To retain A. palmata genetic diversity when restoring damaged coral reefs, Shearer et al. (2009) suggest that fragments from 7-10 donor colonies would retain $50 \%$ of allelic diversity and fragments from 30-35 colonies would retain $90 \%$ diversity. What fraction of that transplanted genetic diversity can be expected to be retained with $3 \%$ survival of transplants at 12 years? Vollmer \& Kline (2008) have proposed an interesting integrated strategy for conserving A. cervicornis, a threatened species that has been decimated by epizootics, has limited sexual recruitment, and has been shown to have low gene flow (Vollmer \& Palumbi, 2007): (1) protect remnant populations that have survived epizootics or other extrinsic insults; and (2) transplant laboratory or maricultured diseaseresistant genotypes. This could be extended to A. palmata, which in this study at this location in this time period appeared to be more robust than A. cervicornis.

\section{CONCLUSIONS}

This project was initiated to test the feasibility of using a non-destructive source of coral transplants by collecting storm-produced coral fragments and to develop a simple, inexpensive method for transplanting fragments that could be conducted by the local community. The ultimate goal was to enhance recovery of important reef-building species that were in decline. The major lessons learned from this 12-year study are: 
- the larger the transplanted fragment, the greater the probability of survival (Garrison \& Ward 2008);

- transplant survival varied among species;

- $\quad$ survival rates of storm-generated coral fragments collected and transplanted to reefs were similar to those of reference colonies;

- inexpensive, inert nylon cable ties effectively attach coral fragments to dead coral skeleton.

- the low survival rates of A. palmata, A. cervicornis, and $P$. porites transplant and reference colonies at 12 years brings into question the efficacy of transplantation for conservation of coral species or reversal of reef degradation;

- coral transplantation will not be effective in conserving coral species or in assisting reef recovery over time until the underlying factors causing degradation of reefs and mortality of corals are understood, addressed, and eliminated or mitigated;

- community involvement is important in building what Brightsmith et al. (2008) call "conservation constituencies," an informed and engaged public that in turn educates the wider community, thereby reducing damage to reefs.

\section{ACKNOWLEDGMENTS}

Thanks go to the National Park Foundation, Canon U.S.A., Inc., and the U.S. Geological Survey for funding the project and to Friends of Virgin Islands National Park, the Trust for Public Land, and Virgin Islands National Park for in-kind support. This research was conducted under NPS permits \#VIIS-2002SCI-0012 (VIIS-0217), VIIS-2004-SCI-0023 (VIIS-04020), and VIIS-2009-SCI-0009 (VIIS09010). We are indebted to: M. Quade, B. Bremser-Nielsen, S. Caseau, D. Downs, J. Garrison, T. Kelley, E. Link, W. Stelzer, R. Waara, 70 community volunteers, and the Pine Peace School 5th- and $6^{\text {th }}$-grade science classes. Thanks to C. Rogers for insightful comments on project design, and to anonymous reviewers for their thoughtful comments. Any use of trade names is for descriptive purposes only and does not imply endorsement by the U.S. Government.

\section{RESUMEN}

En respuesta a la dramática pérdida de corales constructores de arrecifes y la continua falta de recuperación, un proyecto de pequeña escala de transplante de corales, al cual se le dio seguimiento por 12 años, se inició en el Caribe (Islas Vírgenes de EUA) en 1999. Los principales objetivos fueron (1) identificar fuentes de colonias de coral para el trasplante, que no produjeran daños a los arrecifes, (2) evaluar la viabilidad del trasplante de fragmentos de coral generados por tormentas, y (3) desarrollar un método simple y barato para transplantar fragmentos que pudiera ser realizado por la comunidad local. La meta última era aumentar la abundancia de especies constructoras de arrecife amenazadas en los arrecifes locales. Fragmentos de coral producidos por tormenta de dos especies constructoras de arrecife amenazadas [Acropora palmata y A. cervicornis (Acroporidae)] y otras especies de crecimiento rápido [Porites porites (Poritidae)] fueron recolectadas en ambientes no adecuados para la supervivencia de fragmentos de coral y se trasplantaron a los arrecifes degradados. Fajitas de nylon inerte fueron utilizadas para unir los fragmentos de corales transplantados al sustrato de coral muerto. La sobrevivencia de 75 colonias de referencia y de 60 transplantadas fueron monitoreadas por más de 12 años. Sólo el $9 \%$ de las colonias estaban vivas tras 12 años, sin presencia de A. cervicornis, el 3\% de los transplantes de $A$. palmata y el $18 \%$ de las colonias de referencia de Acropora. El $13 \%$ de los transplantes de $P$. porites y el $7 \%$ de las colonias de referencia sobrevivieron. El desprendimiento físico resultó en la pérdida del $56 \%$ de las colonias, mientras que el $35 \%$ murió en el lugar. Solamente A. palmata mostró una diferencia en sobrevivencia entre los trasplantes y las colonias de referencia, eso fue solo en el primer año. La ubicación fue un factor en la sobrevivencia sólo para las colonias de referencia de A. palmata y después de 10 años. A pesar de que los métodos y los conceptos fueron probados efectivamente en el campo por más de 12 años de estudio, no mostraron ser la solución. Ninguna estrategia de conservación va a ser efectiva hasta que se delimiten y sean entendidos, mitigados o eliminados los factores intrínsecos y/o extrínsecos que conducen a las altas tasas de mortalidad.

Palabras clave: Acropora cervicornis, A. palmata, mortalidada de coral, Porites porites, restauración de arrecifes, transplantes de corales 


\section{REFERENCES}

Aronson, R.B. \& W.F. Precht. 1997. Stasis, biological disturbance, and community structure of a Holocene coral reef. Paleobiology 23: 326-346.

Aronson, R.B. \& W.F. Precht. 2001. Evolutionary paleoecology of Caribbean coral reefs, p. 171-233. In W.D. Allmon \& D.J. Bottjer (eds). Evolutionary Paleoecology: The Ecological Context of Macroevolutionary Change. Columbia University Press, New York.

Baums, I.B. 2008. A restoration genetics guide for coral reef conservation. Mol. Ecol. 17: 2796-2811.

Birkeland, C. 2004. Ratcheting down the coral reefs. BioScience 54: 1021-1027.

Bowden-Kerby, A. 2001. Low-tech coral reef restoration methods modeled after natural fragmentation processes. B. Mar. Sci. 69: 915-931.

Bowden-Kerby, A. 2009. Restoration of threatened Acropora cervicornis corals: intraspecific variation as a factor in mortality, growth, and self-attachment. Proceedings of the $11^{\text {th }}$ Intl. Coral Reef Symp., Ft. Lauderdale, Florida 2: 1194-1198.

Brightsmith, D.J., A. Stronza \& K. Holle. 2008. Ecotourism, conservation biology, and volunteer tourism: A mutually beneficial triumvirate. Biol. Conserv. 141: 2832-2842.

Bruckner, A.W. \& R.J. Bruckner, 2001. Condition of restored Acropora palmata fragments off Mona Island, Puerto Rico, 2 years after Fortuna Reefer ship grounding. Coral Reefs 20: 235-243.

Bruckner, A.W. \& R.J. Bruckner. 2006. Survivorship of restored Acropora palmata fragments over six years at the M/V Fortuna Reefer ship grounding site, Mona Island, Puerto Rico. Proceedings of the $10^{\text {th }}$ Intl Coral Reef Symp., Okinawa, Japan 1: 1645-1650.

Bruckner, A.W., R.J. Bruckner \& R. Hill. 2009. Improving restoration approaches for Acropora palmata: Lessons from the Fortuna Reefer grounding in Puerto Rico. Proceedings of the $11^{\text {th }}$ Intl. Coral Reef Symp. Ft. Lauderdale, Florida 2: 1199-1203.

Bruno, J.F. \& E.R. Selig. 2007. Regional decline of coral cover in the Indo-Pacific: Timing, extent, and subregional comparisons. PLos ONE 8: e711.

Bruno, J.F., E.R. Selig, K.S. Casey, C.A. Page, B.L Willis, C.D. Harvell, H. Sweatman \& A.M. Melendy. 2007. Thermal stress and coral cover as drivers of coral disease outbreaks. PLoS Biol. 5: e124.
Edwards, A.J. \& S. Clark. 1998. Coral transplantation: A useful management tool or misguided meddling? Mar. Pollut. Bull. 37: 474-487.

Edwards, A.J. \& E.D. Gomez. 2007. Reef restoration concepts and guidelines: Making sensible management choices in the face of uncertainty. Coral Reef Targeted Research \& Capacity Building for Management Programme, St. Lucia and Australia 4: 1-38.

Epstein, N., M.J.A. Vermeij, R.P.M. Bak \& B. Rinkevich. 2005. Alleviating impacts of anthropogenic activities by traditional conservation measures: Can a small reef reserve be sustainably managed? Biol. Conserv. 121: 243-255.

Forrester, G.E., C. O'Connell-Rodwell, P. Baily, L.M. Forrester, S. Giovannini, L. Harmon, R. Karis, J. Krumholz, T. Rodwell \& L. Jarecki. 2011. Evaluating methods for transplanting endangered Elkhorn Corals in the Virgin Islands. Restor. Ecol. 19: 299-306.

Gardner, T.A., I.M. Côté, J.A. Gill, A. Grant, \& A.R. Watkinson. 2003. Long-term region wide declines in Caribbean coral reefs. Science. 301: 958-960.

Garrison, V. \& G. Ward. 2008. Storm-generated coral fragments - A viable source of transplants for reef rehabilitation? Biol. Conserv. 141: 299-306.

Hughes, T.P. 1994. Catastrophes, phase shifts and largescale degradation of a Caribbean coral reef. Science 265: 1547-1551.

Jaap, W.C., J.H. Hudson, R.E. Dodge, D. Gilliam \& R. Shaul. 2006. Coral reef restoration with case studies from Florida: p. 478-514. In M. Côte \& D. Reynolds (eds.). Coral Reef Conservation. Univ. Cambridge Press, Cambridge, UK.

Kaufman, L. 2006. If you build it, will they come? Toward a concrete basis for coral reef gardening: p. 119142. In W.F. Precht (ed). Coral Reef Restoration Handbook. Chemical Rubber Company, Taylor and Francis, Boca Raton, Florida.

Knowlton, N. 2006. Coral reef coda: What can we hope for?: p. 538-549. In M. Côte \& D. Reynolds (eds). Coral Reef Conservation. Univ. Cambridge Press, Cambridge, UK.

Miller, J., E. Muller, C. Rogers, R. Waara, A. Atkinson, K. R. T. Whelan, M. Patterson \& B. Witcher. 2009. Coral disease following massive bleaching in 2005 causes $60 \%$ decline in coral cover on reefs in the US Virgin Islands. Coral Reefs 28:925-937.

Muller, E., C.S. Rogers, A.S. Spitzack, \& R. van Woesik. 2008. Bleaching increases likelihood of disease on 
Acropora palmata (Lamarck) in Hawksnest Bay, St. John, U.S. Virgin Islands. Coral Reefs 27: 191-195.

Mumby, P.J. \& R.S. Steneck. 2008. Coral reef management and conservation in light of rapidly evolving ecological paradigms. Trends Ecol. Evol. 23, 555-563.

Normile, D. 2009. Bringing coral reefs back from the living dead. Science 325: 559-561.

Nyström, M., N.A.J. Graham, J. Lokrantz, \& A.V. Norström, 2008. Capturing cornerstones of coral reef resilience: Linking theory to practice. Coral Reefs 27: 795-809.

Pandolfi, J.M., J.B.C. Jackson, J.B.C., N. Baron, R.H Bradbury, H.M. Guzmán, T.P. Hughes, C.V. Kappel, F. Micheli, J.C. Ogden, H.P. Possingham \& E. Sala. 2005. Are US coral reefs on the slippery slope to slime? Science 307: 1725-1726.

Peng, C.J., K.L. Lee \& G.M. Ingersoll. 2002. An introduction to logistic regression and reporting. J. Educ. Res. 96: 3-14.

Rinkevich, B. 1995. Restoration strategies for coral reefs damaged by recreational activities: The use of sexual and asexual recruits. Restor. Ecol. 3: 241-251.

Rinkevich, B. 2005. Conservation of coral reefs through active restoration measures: Recent approaches and last decade progress. Environ. Sci. Technol. 39: 4333-4342.

Rinkevich, B. 2008. Management of coral reefs: We have gone wrong when neglecting active reef restoration. Mar. Pollut. Bull. 56: 1821-1824.

Ritchie, K. 2006. Regulation of microbial populations by coral surface mucus and mucus-associated bacteria. Mar. Ecol. Prog. Ser. 322: 1-14.

Roberts, C.M., J.D. Reynolds, I.M. Côte \& J.P. Hawkins. 2006. Redesigning coral reef conservation: p. 515-537. In M. Côte \& D. Reynolds (eds). Coral Reef Conservation. Univ. Cambridge Press, Cambridge, UK.

Rogers, C.S. 1999. Dead Porites patch reefs, St. John, US Virgin Islands. Coral Reefs 18: 1254.
Rogers, C.S., E.M. Muller, A. Spitzack, \& J. Miller. 2009. The future of coral reefs in the US Virgin Islands: Is Acropora palmata more likely to recover than Montastraea annularis complex? Proceedings of the 11th Intl. Coral Reef Symp., Ft. Lauderdale, Florida 1: $226-230$

Rosenberg, E., O. Koren, L. Reshef, R. Efrony \& I. ZilberRosenberg. 2007. The role of microorganisms in coral health, disease and evolution. Nat. Rev. Microbiol. 5: $355-362$.

Shearer, T.L., I. Porto \& A.L. Zubillaga. 2009. Restoration of coral populations in light of genetic diversity estimates. Coral Reefs 28: 727-733.

Singer, J.D. \& J.B. Willett. 2003. Applied Longitudinal Data Analysis: Modeling Change and Event Occurrence. Oxford University Press, New York.

Teplitski, M. \& K. Ritchie. 2009. How feasible is the biological control of coral diseases? Trends Ecol. Evol. 24: $378-385$.

Vargas-Ángel, B. \& J.D. Thomas. 2002. Sexual reproduction of Acropora cervicornis in nearshore waters off Ft. Lauderdale, Florida, USA. Coral Reefs 21: 25-26.

Vargas-Ángel, B., J.D. Thomas \& S.M. Hoke. 2003. High-latitude Acropora cervicornis thickets off Fort Lauderdale, Florida, USA. Coral Reefs 22: 465-473.

Vollmer, S.V. \& D.L. Kline. 2008. Natural disease resistance in threatened staghorn corals. PLoS ONE 3: e3718.

Vollmer, S.V. \& S.R. Palumbi. 2007. Restricted gene flow in the Caribbean staghorn coral Acropora cervicornis: Implications for the recovery of endangered reefs. J. Hered. 98: 40-50.

Williams, D.E. \& M.W. Miller. 2010. Stabilization of fragments to enhance asexual recruitment in Acropora palmata, a threatened Caribbean coral. Restor. Ecol. 18 (S2): 446-451.

Young, T.P. 2000. Restoration ecology and conservation biology. Biol. Conserv. 92: 73-83. 